\title{
Cataract surgery in Knobloch syndrome: a case report
}

This article was published in the following Dove Press journal:

Clinical Ophthalmology

I June 201 I

Number of times this article has been viewed

\section{Carmen Sílvia Bongiovanni' \\ Carla Cristina Serra \\ Ferreira' \\ Ana Paula Silvério \\ Rodrigues' \\ João Borges Fortes Filho \\ Márcia Beatriz Tartarella' \\ 'Department of Ophthalmology, Congenital Cataract Section, Medical School, Federal University of São Paulo, São Paulo; ' ${ }^{2}$ Department of Ophthalmology, Medical School, Federal University of Rio Grande do Sul, Porto Alegre, Brazil}

Correspondence: Márcia Beatriz Tartarella Department of Ophthalmology, Medical School, Federal University of São Paulo, Rua Passo da Pátria, 1678/92, Sao Paulo, Brazil 05085-000

Tel +55 II 38339469

Fax +55 II 38339469

Email tartarella@yahoo.com

\begin{abstract}
Knobloch syndrome is an autosomal recessive disorder associated with early-onset ocular abnormalities and central nervous system malformations. Ocular abnormalities are usually severe, and include high myopia, vitreoretinal degeneration, retinal detachment, macular abnormalities, and cataract. The most frequent systemic changes are midline malformations of the brain, ventricular dilation, and occipital encephalocele. Cognitive delay may occur. We report a case of cataract in a child with Knobloch syndrome. Cataract surgery and follow-up are described.
\end{abstract}

Keywords: Knobloch syndrome, cataract, phacoemulsification, vitreous, right eye, left eye, genetic

\section{Case report}

The proband, a 12-year-old Caucasian male, was referred to the Congenital Cataract Section of the Federal University of Sao Paulo, Brazil, complaining of progressive loss of vision. External observation showed bilateral leukocoria and right exotropia. The best corrected visual acuity was counting fingers at $0.5 \mathrm{~m}$ in each eye.

Slit-lamp examination revealed a total cataract in the right eye, and a nuclear and posterior subcapsular cataract in the left eye. Goldmann tonometry was $11 \mathrm{mmHg}$ and $10 \mathrm{mmHg}$, respectively, in the right and left eyes. Right eye fundus examination was not feasible due to total cataract. Fundus examination of the left eye showed a myopic fundus with vitreous detachment and myopic macular scarring.

Thin lenses and a probable posterior staphyloma in both eyes were identified by ultrasonography. Vitreous opacities resembling the presence of posterior fetal vasculature were detected in the right eye (Figure 1). The axial length was $27.8 \mathrm{~mm}$ and $27.5 \mathrm{~mm}$, respectively, in the right and left eyes. The patient had no systemic changes or delay in neuropsychomotor development.

The proband's brother was blind secondary to bilateral retinal detachment and aphakia. Consanguinity was detected in their parents, who were first cousins. A prior familial genetic study had been performed at another institution before the referral of the proband to our service. The familial genetic diagnosis was Knobloch syndrome type I. The parents and one proband's sister had a normal eye examination without systemic features. The proband, as part of the present examination, also underwent a genetic study, which disclosed the same genetic diagnosis (Knobloch syndrome type I).

Phacoemulsification in the right eye was performed under general anesthesia, given the patient's age. A limbal incision, anterior capsulorhexis, and nucleus fragmentation were performed. A peroperative posterior capsular rupture occurred. There was no 


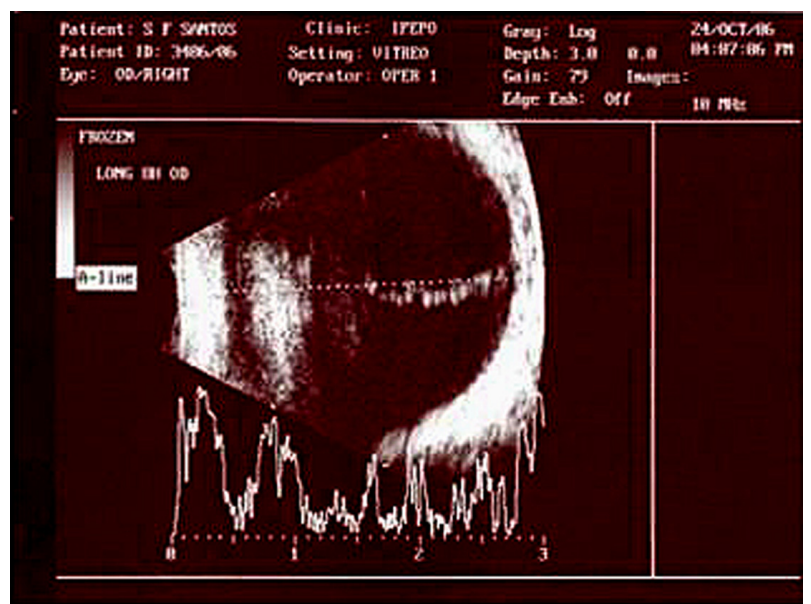

Figure I Retinal echography showing vitreous opacities resembling a persistence of fetal vasculature.

vitreous prolapse and it was possible to implant an intraocular lens within the capsular bag.

On the first day of follow-up, findings were unremarkable. At one-week follow-up, slit-lamp examination showed an inflammatory reaction in the anterior vitreous and anterior chamber, despite use of topical and systemic steroids. Two months after surgery, visual acuity had improved to 20/200 in the right eye, and the patient switched to a left exotropia. A progressive posterior capsular opacity was detected in the visual axis, and a neodymium YAG laser capsulotomy was performed in the right eye. One year after surgery, dislocation of the intraocular lens was observed by slit-lamp examination. Ultrasound biomicroscopy showed a displaced intraocular lens behind the ciliary body at 7-8 clock hours. The intraocular lens haptic was dislocated to the inferior temporal quadrant (Figure 2). A scleral intraocular lens fixation and anterior vitrectomy were performed to reposition the intraocular lens.

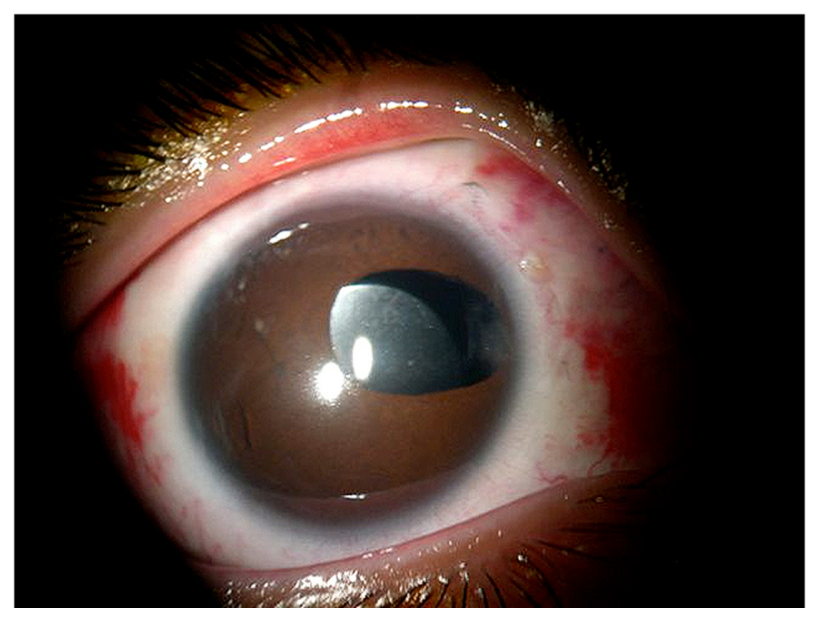

Figure 2 Dislocation of intraocular lens.
One year later, a phacoemulsification was performed in the patient's left eye due to considerable progression of the pre-existing lens opacity to a total cataract. A limbal incision, anterior capsulorhexis, and nucleus fragmentation were done. A peroperative posterior capsular rupture occurred, as had previously happened during the patient's right eye surgery. At this time, there was no capsular support to perform a safe intraocular lens implantation, and the left eye was left aphakic. Visual acuity with best corrected refraction improved from counting fingers to 20/200 in the left eye. The visual axis remained clear in both eyes, with final best corrected visual acuity of 20/200, leading to a better quality of life for the patient.

\section{Discussion}

This case report describes the outcomes of cataract surgery in a patient with Knobloch syndrome type I, an autosomal recessive disease affecting collagen XVIII. It was first described by Knobloch and Layer in 1971. ${ }^{1}$ The pattern of inheritance is related to consanguinity. There are ocular and systemic clinical features. ${ }^{2,3}$ Ocular abnormalities include high myopia, vitreoretinal degeneration and opacities, retinal detachment, macular abnormalities, and cataract. ${ }^{4}$

Ocular abnormalities are present in all cases reported in the literature, with great variability of clinical manifestations, due to the large number of mutations that occur in the gene. There are reports of cases of Knobloch syndrome associated with the persistence of primary vitreous. ${ }^{1,5}$ There is no previous report of cataract surgery in Knobloch syndrome, according to a recent PubMed search using "Knobloch syndrome" and "cataract" as keywords.

Collagen XVII is responsible for a proteoglycan component of basement membranes, including those of the iris, retina, and vitreous. It plays a role in eye development and maintenance of visual function. ${ }^{6,7}$

Planning cataract surgery in patients with Knobloch syndrome requires attention to the modified structure of the collagen, probably causing alterations and weakness of the zonula and lens capsule. ${ }^{5}$ An intense inflammatory response may also occur after surgery, especially in children. $^{8}$

Knobloch syndrome should be monitored due to the risk of complications during or after phacoemulsification surgery. It is very important to consider the risk of retinal detachment in these patients. Genetic analysis in a specialized laboratory is necessary to confirm the diagnosis of Knobloch syndrome. 


\section{Disclosure}

The authors declare no financial support or relationships that may pose a conflict of interest in this work.

\section{References}

1. Knobloch WH, Layer JM. Persistence of fetal vasculature in a patient with Knobloch syndrome, potential role for endostatin in fetal vascular remodeling of the eye, retinal detachment and encephalocele. J Pediatr Opthalmol. 1971;8:181-184.

2. Passos-Bueno MR, Suzuki OT, Armelin-Correa LM, et al. Mutations in collagen 18A1 and their relevance to the human phenotype. An Acad Bras Cienc. 2006;78(1):123-131.

3. Passos-Bueno MR, Marie SK, Monteiro M, et al. Knobloch syndrome in a large Brazilian consanguinous family: Confirmation of autosomal recessive inheritance. Am J Med Genet. 1994;52(2):170-173.

4. Sertie AL, Quimby M, Moreira ES, et al. A gene which causes severe ocular alterations and occipital encephalocele (Knobloch syndrome) is mapped to 21q22.3. Hum Mol Genet. 1996;5(6):843-847.
5. Duh EJ, Yao YG, Dagli M, Goldberg MF. Persistence of fetal vasculature in a patient with Knobloch syndrome: Potential role for endostatin in fetal vascular remodeling of the eye. Ophthalmology. 2004;111(10):1885-1888.

6. Sertie AL, Sossi V, Camargo AA, Zatz M, Brahe C, Passos-Bueno MR. Collagen XVIII, containing an endogenous inhibitor of angiogenesis and tumor growth, plays a critical role in the maintenance of retinal structure and in neural tube closure (Knobloch syndrome). Hum Mol Genet. 2000;9(13):2051-2058.

7. Mahajan VB, Olney AH, Garrett P, Chary A, Dragan E, Lerner G, et al. Collagen XVIII mutation in Knobloch syndrome with acute lymphoblastic leukemia. Am J Med Genet Part A. 2010;152A(11):2875-2879.

8. Tartarella MB, Verçosa I. Técnicas cirúrgicas da catarata na criança [Surgical techniques for cataract in children]. In: Verçosa I, Tartarella MB editors. Catarata na Criança [Cataract in Children]. Fortaleza, Brazil: Editora Celigráfica; 2008.
Clinical Ophthalmology

\section{Publish your work in this journal}

Clinical Ophthalmology is an international, peer-reviewed journal covering all subspecialties within ophthalmology. Key topics include: Optometry; Visual science; Pharmacology and drug therapy in eye diseases; Basic Sciences; Primary and Secondary eye care; Patien Safety and Quality of Care Improvements. This journal is indexed on

Submit your manuscript here: http://www.dovepress.com/clinical-ophthalmology-journal

\section{Dovepress}

PubMed Central and CAS, and is the official journal of The Society of Clinical Ophthalmology (SCO). The manuscript management system is completely online and includes a very quick and fair peer-review system, which is all easy to use. Visit http://www.dovepress.com/ testimonials.php to read real quotes from published authors. 